\title{
Aesthetic Valuen alues of Classical Batik as the Source of Contemporary Painting Ideas
}

\author{
Adam Wahida ${ }^{1}$, Endang Sri Handayani ${ }^{2}$, Figur Rahman Fuad ${ }^{3}$ \\ ${ }^{1}$ Department of Art Education, Universitas Sebelas Maret, Surakarta, Indonesia \\ ${ }_{3}^{2}$ Department of Art Education, Universitas Sebelas Maret, Surakarta, Indonesia \\ ${ }^{3}$ Department of Art Education, Universitas Sebelas Maret, Surakarta, Indonesia
}

adamwahida@staff.uns.ac.id (Adam Wahida), endangsri71@staff.uns.ac.id (Endang S. Handayani), figurrahmanfuad@staff.uns.ac.id (Figur R. Fuad)

\begin{abstract}
As one of the Javanese culture centers, Surakarta is known to have batik tradition that has reached the top of the classical ones. The Surakarta classical batiks have taught the values of ideals, life expectancies, existences, establish-ments, behaviors, glories, and noble guidance as contained in the symbols of classical batik patterns: sidoasih, sidomukti, sidodrajat, which are still used by the people in various traditional ceremonies or important events. The philosophical values within Surakarta classical batiks can be extracted and used as a source of inspiration to create contemporary artworks. Materials that are related to the forms, meanings, norms and values of traditional aesthetics can be developed, explored, and linked to the present life. This research aims to create contemporary artworks with local characters. The creation methods of these works include: exploration, incubation, illumination, and verification/ production. The method is elaborated in several steps: analyzing the documents, determining the ideas and themes of painting, sketching/ creating the designs of the painting, selecting the media and techniques, and producing the painting. This research has produced 3 pieces of contemporary paintings through the development of ideas, themes, and visual forms of classical batik of Surakarta. Visually the paintings are made with a photographic painting technique that considers the aspects of visual illusion such as: perspective, light and shadow, and also chiaroscuro. Philosophically, those works represent aesthetic values of classical batik and contain symbolic meanings that are relevant to the life condition today.
\end{abstract}

Keywords aesthetic, painting, classical batik

\section{Introduction}

Modernization has an impact on the development of art in the city of Surakarta which has very bold traditional Ja-vanese arts. Modernization and advancement of informationtechnology have triggered the growth of the contemporaryart genre that brings novelty and is reliable to the current conditions. As a new genre, contemporary painting is not bounded by the earlier rules (pakem), but it develops along the time. The idea of its creation often uses the strategy of borrowing forms from different cultures. Modern technology images such as speed, simplicity, rationality, metallic im- pression, and accuracy are expressed in the shapes, lines, colors, and materials of the artworks to reveal the novelty of the visual aspects (Haryanto, 2015: 4). Although the work looks new, through the practice of contemporary art which is influenced by that modern image, it is hard to find any 'local identity' in it. Visually, the re- sulting artworks are seen stereotypical and have similarity in their modern images; the works of different artists is difficult to distinguish and lack of the cultural characters. Under these conditions, an artist needs to have a good control over his creation process. Furthermore, for those living in Surakarta, they need to explore the traditional or classical artworks to find the contained aesthetic and philosophical values so that the resulting artworks have strong identity and character. One of the Surakarta traditional artworks that can be used as a source of inspiration for a painting creation is a classical batik. As a legacy of Surakarta traditions, classical batik is still preserved by the society today. Its usage in the form of jarit cloth still exists in almost all important ceremonies/ ritual traditions in the region of Surakarta. Classical batik is believed to be the reflection of the skills, concep- tions, and ideologies of the society. Aesthetically, its visual patterns contain much symbolic strength representing pro- found and philosophical values. Surakarta classical batik teaches many values about ideals, life expectancies, exist- ences, establishments, behaviors, glories, and noble guid- ance, similar to the philosophical values contained in the symbols of batik patterns: sidodadi, sidomulyo, sidomukti, sidodrajat, and sidoluhur (Budi, 2017: 39-44). Based on the previous thoughts, the aesthetic values of Surakarta classical batik can be used as the basis and source of inspirations to create contemporary paintings. Materials related to the shapes, meanings, norms, and aesthetic values can be developed, explored and linked to 
today"s life. Thus, the character values and local wisdom will be implemented in the ideas, themes, shapes, techniques, and media of con-temporary paintings which are corresponding to the zeit-geist but still have the identity and character.

In general, this study aims to rediscover the wisdom and aesthetics values in Surakarta classical batik so that it can be used as a creation source of contemporary paintings that have strong character and identity. Specifically, it aims to create a contemporary painting with the development of ideas, themes, and visual forms based on Surakarta classical batik aesthetic through photographic painting technique.

Globalization has caused Western values, models, and parameters to be more diffuse, trendy, and seductive. Information technology has also made it easy for the Eastern artists to know and understand the latest development of art discourses in Western. The discourse of contemporary art and its parameters formed by the Western art scene can easily influence Indonesia. The problem is that the latest artworks influenced by the Western-style tend to have a gap between the artists and the appreciators. In this context, Indonesian contemporary arts are at a risk of losing the areas that are not recognized and understood by the people (Irianto, 2005: 72-73). Nevertheless, the barriers loss due to the global in-teraction has also introduced the arts to the multicultural characters. Nowadays, the art world is very open to various 'aesthetic' forms of local cultures (Sugiharto, 2016: 3). Be-cause of its multicultural nature, an artwork plays important role to develop social sensitivity, instill the awareness of the differences and the diversity of cultures, and appreciate the cultures, so that the values in them can provide inspirations (Sustiawati, 2009: 3).

Observing the contemporary art opportunity can possi-bly make the artworks become a ,politicale area to carry the deeply rooted local culture identity. Contemporary arts can also be used as a ,struggle ${ }^{e e}$ and „emancipation" tool for marginal art community. Therefore, the 'identity politics' becomes important in the discourse and praxis of contem-porary art, so that it will not cause unease (Nairne, 1999: 113). Primadi Tabrani (1999: 1-4) states that in the global era an artwork is not enough if it only meets the international standards, it also needs to have the local characteristics. It will be useful to preserve the traditional arts as well as to develop the tradition-based works to be ready to compete in the global market.

The character values contained in Surakartaees artworks such as classical batik can be used as the inspiration for creating new artworks that represents the current develop-ments. Besides having a wide range of visual aesthetics, the traditional artworks contain philosophical meanings about life lessons that are still relevant to the present situation, for example, the classical sidoasih batik pattern of which main ornament is the form of fruit in wadah (container, of which is a basket) and supporting ornaments in the form of: large pistil ornaments, large petals, and constructions/ temples tied with confirming ornament in the form of curved lines that represent dhadhung (tali). Fruit as a symbol in batik means hope and belief (Fraser Lu, 1985: 43). Based on Karma Yoga (Hindu) teaching, fruit symbolize obedience and obligation which means that action is a responsibility.

Meanwhile, the building/ temple has a meaning as a settled residence and surrounded by prosperity (Torwesten, 1991: 98). Fruit and flowers in wadah mean love rising from purity and filled with fertility. The crossing of the curved rope (dhadhung) means a strong and mutually reinforcing for-mation, interconnected and inseparable, and mutually un-derstanding each other with flexibility. Besides its visual aspects that are rich in meaning, the sidoasih pattern name also contains philosophical meaning. „Sidoasihee is derived from the word ,sido ${ }^{\text {ee }}$ which means, ,realizing the willee or „something wished to be happened"e and ,asih" which means „love $e^{e}$. Thus, the classical sidoasih batik pattern means a „life guide ${ }^{e e}$ in a kind and responsible love, as well as the things that must be fulfilled in order to build the loving re-lationship (Budi, 2017: 38-39). The philosophical values contained in those Surakarta's classical batiks are still rele-vant to the present life so that they are potential to be inte-grated and developed into the creation of new artworks.

\section{Creation Method}

The art-making method is formally followed by struc-tured stages as well as the unexpected, spontaneous, and intuitive ones. In this creation process, the stages are based on David Campbelles ideas: (1) preparation, to learn about the background and problems related to the Surakarta clas-sical batik; (2) concentrating to contemplate fully and deep into the art-creation process; (3) incubation, taking time to leave all the matters in the art-creation process, resting, and settling it; (4) illumination, determining the ideas, solving the problems, completing, procedures and the new answers,

(5) verification/ production, formulating a work plan, real-izing the ideas and creating the paintings (Campbell, 1986: 18).

\section{Findings and Discussion \\ Exploration}

The exploration process of creating these artworks is started by studying/examining the subject matter related to the aesthetic and philosophical aspects of the Surakarta classical batik, such as: sidoasih, sidomulyo, sidodrajat. The aesthetic values of those three patterns are unraveled to learn about their visual elements and philosophical mean-ings.

This exploration process results in finding the basic patterns, visual elements, main ornaments, supporting ornaments, and proponent ornaments. To trigger the ideas, the results are then formally analyzed and semantically inter-preted.

\section{Sidoasih Pattern}

The visual elements of sidoasih pattern consist of: one big rhombus-shaped design made of nine smaller rhombus-es. Each small rhombus is filled with different ornaments, such as fruits in a basket, flower petal, pistil, bird"'s wing, and building/ house. In the bigger rhombus, there are one main pattern, four supporting patterns, four proponent pat-terns, and one confirming ornament.

One main pattern consists of the fruits in a basket or-nament in white background filled with isen-isen 
(filler) lunglungan or vine ornament. The four supporting patterns

consist of some ornaments, including: a flower with big petal, a single wing, a flower with big petal, and a building. Each ornament is placed in the center of each rhombus with dark brown background filled by kembang pari or the rice flower ornament. The four proponent patterns consist of two different ornaments: flower with big petal and fruits in a basket which are placed in the center of the rhombus with white background and filled by the vine. At last, the con-firming ornament is formed by dhadhung or twisted rope in brown color which is used as the border of the rhombuses.

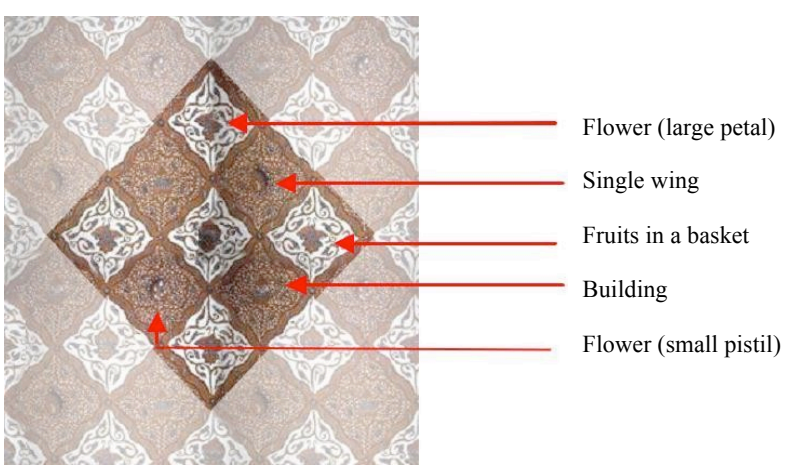

Figure 1. Ornament identification of sidoasih pattern

Besides analyzing the elements of sidoasih pattern, the exploration process exposes the meaning by interpreting the word ,sidoasih'. In Javanese, the word ,sido" means realizing the will or something wished to be happened, while the word ,asih"e means love, passion, kindness, sym-pathy, and generosity. Therefore, the word ,sidoasih ${ }^{\text {ee }}$ can be interpreted as a willingness to complete everything with love.

\section{Sidomulyo Pattern}

Based on the pattern, sidomulyo has some similarities with sidoasih pattern, which is the rhombus design filled with ornaments. However, the main elements in sidomulyo pattern consist of four ochre colored rhombuses. Each rhombus is filled by different main ornaments: a butterfly, a single wing, a flower with small pistil, and a building; while the supporting ornaments that surround the main ornaments consist of lung-lungan or vine. Each side of those four rhombuses is made of dhadhung ornaments or twisted ropes which are arranged repetitively. On each crossing of the ropes, there is flower with small petals.

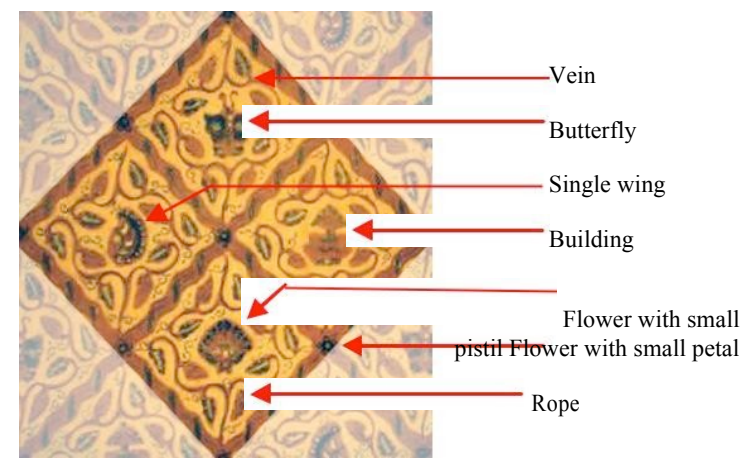

Figure 2. Ornament identification of sidomulyo pattern
The meaning of „mulyo" in Javanese is identical with the word ,noblee, which means: respected, prudent, kind hearted, and highly valued. Thus, semantically, the word ,sidomulyo"e means a willingness to achieve the glory, or the highly respected existence.

\section{Sidodrajat Pattern}

The visual elements of sidodrajat pattern consist of vertically arranged rhombuses which are filled with four different ornaments: flower and vein, gringsing, small flowers (truntum), and single wing in semen composition. The top rhombus has flower and vein ornaments in white background, the next two rhombuses are in brown (sogan) background with black (kelengan) gringsing design and in kelengan background with truntum (small flowers) design, and the last rhombus has a single wing ornament and is filled with vein. The last rhombus is the center point for the repetitive pattern of sidorajat design.

The word „drajate in Javanese refers to „position ${ }^{\text {ee }}$ or „social statuses"e. Therefore, philosophically, sidodrajat means prayer and hope for ease in gaining prosperity, drajat and noble position.

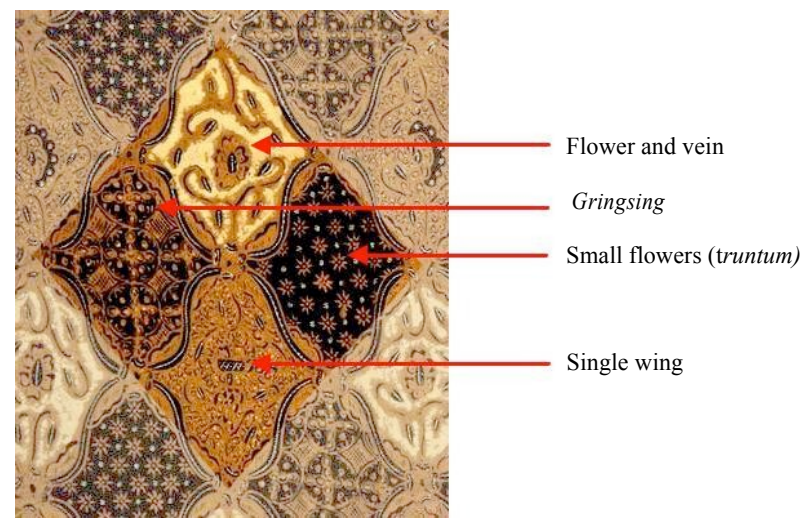

Figure 3. Ornament identification of sidodrajat pattern

\section{Incubation}

After finding some symbolic and aesthetic values of those three patterns, in this stage the problems dealing with the source of ideas are left aside for a moment. The prob-lems are settled while looking for another refreshing thing to gather new ideas.

\section{Illumination}

In the illumination process, some possible ideas are re-alized by creating sketches, deciding the techniques, mate-rials, and painting formats. Some of the sketches to be drawn later are shown as follows:

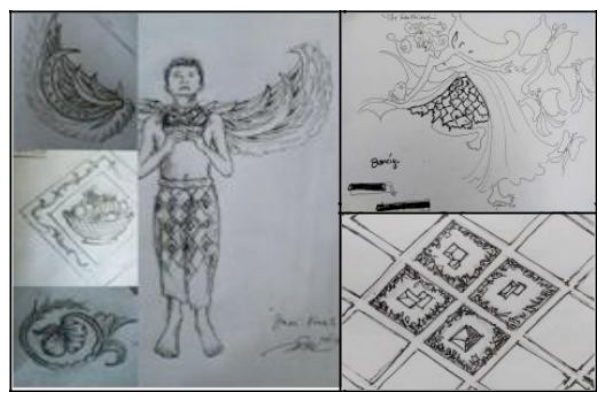

Figure 4. Sketches inspired by the classical patterns 


\section{Verification/ Production}

After creating some sketches and plans, the ideas to be drawn in the paintings are decided in the verification/ production process. Generally, the paintings are produced by applying the photographic technique, by making use the optical illusions such as perspective, light and shadow, and chiaroscuro. Additionally, the style of the paintings belongs to the symbolic painting.

The production process begins with the setting of the model/ main object with the help of photography. It is then edited using Photoshop software to get the desired compo-sition. The result of the Photoshop image is then used as the guidance in the production process. The final design is de-veloped into a painting using acrylic on a canvas.

\section{Painting 1, Demi Kasih}

The idea of this painting is from sidoasih batik. The main object is a young boy wearing sidoasih batik without shirt. He is gazing upward while holding a basket of fruit. He is standing oh his tiptoes on a plate placed over a red rope which is settled horizontally. Behind him is a pair of bird"s wings wide-open.

Based on the chosen sketch and Photoshop design, the visual is developed by adding contrast between the object and the main background. The main object is made using photographical painting technique, while the background is made with dripping technique. The background color is gradation of dark brown at the bottom to light yellow at the top of it.

The main object of a young man standing and gazing upward represents a wishful prayer or requesting a hope. The fruit in a basket symbolizes love and prosperity. The open wings are the symbols of a life journey. Finally, the plate on a single rope symbolizes strength and balance.

This painting represents a hope or will to achieve everything becomes a love in transcendence. The modern life which is full of competitions and all its problems is not supposed to be the human"s problem as long as they have the desire to live peacefully in harmony and love.

The source of the inspiration. Although it is presented in a contemporary-style of photographic painting image, the symbolic meanings can represent the philosophical values of sidoasih pattern. Therefore, the creation of this painting has given a shape to the local values which are still relevant to the present life.

\section{Painting 2, Kota Harapan}

This painting is based on the glory concept within si-domulyo pattern. According to the Javanese philosophy, glory in existence can be reached if human protects his four desires: amarah, lawwamah, supiyah, and mutmainah. The control of those four will balance the life which then be reflected in the harmonious relationship between human and nature. In this painting, that idea is linked to the hous-ing condition in the city which is usually full of buildings. The plants are cut down only to build the human shelters.

The basic pattern of sidomulyo, rhombus design, is used as the basic composition of this painting. It is a land-scape painting showing a housing area in a city arranged geometrically and surrounded by trees and water similar to the ones represented in sidomulyo pattern consisting buildings, plants, and animals as a single existence of hu-man and nature.

The ideal glory in Javanese philosophy refers to the results of human"s attitude in preserving the nature. They believe that the good things will be back to those who do well; for example, by planting trees around their living places, human will eventually get the clean and fresh air.

The visualization of the housing landscape looks like a mosaic with repetitive basic pattern. The similar design on sidomulyo can be interpreted that the idea of living in bal-ance with the nature is a collective ideal that has to be done together with individuals"e ability as represented on this painting.

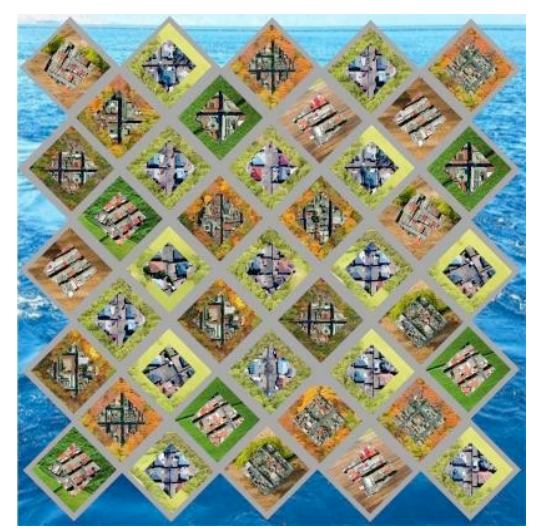

Figure 5. Demi Kasih, 120 x $145 \mathrm{~cm}$, acrylic on canvas, 2017

Taking a close look at this painting"s (Demi Kasih) visual, there are some aesthetic values of sidoasih pattern as

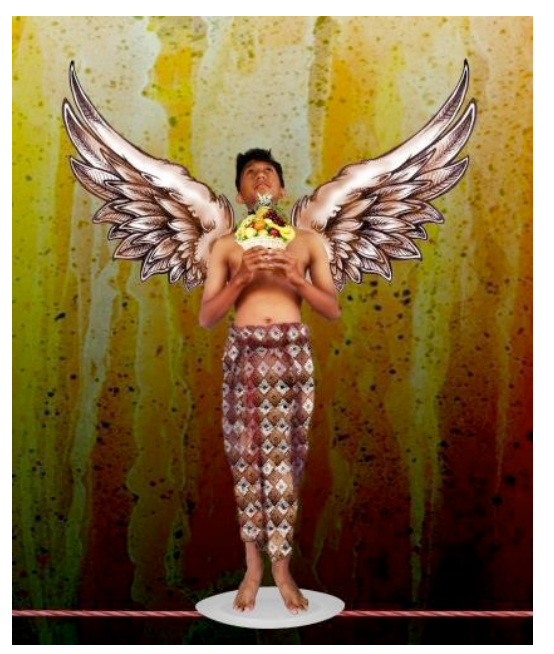

Figure 6. Kota Harapan, $150 \times 150 \mathrm{~cm}$, acrylic on canvas, 2017

\section{Painting 3, Tarian Terbang}

The idea of this painting is sidodrajat pattern. The main object of this painting is a dancing women wearing batik cloth with sidodrajat pattern. She looks moving with one leg raised and a waiving shawl in the air, while wearing sidodrajat batik with torn edges. Her right hand 
is holding a pink heart and there are butterfly wings at her back.

This dancing woman in this painting represents dynamic moves of a married woman. Her wings illustrate her

great ideals. The bowing gesture while holding a heart rep-resents her strong will in keeping the marriage, while the torn sidodrajat pattern shows how her dreams and hopes are fallen apart.

As a whole, this painting represents the reality of dreams, prayers, and hopes that are sometimes too difficult to be granted in onese live, especially women. Women are blessed with dreams and hope to become a noble person as an adult. However, her education is sometimes only used to get a high position in their careers without realizing that the other knowledge are important to attain an essential life.

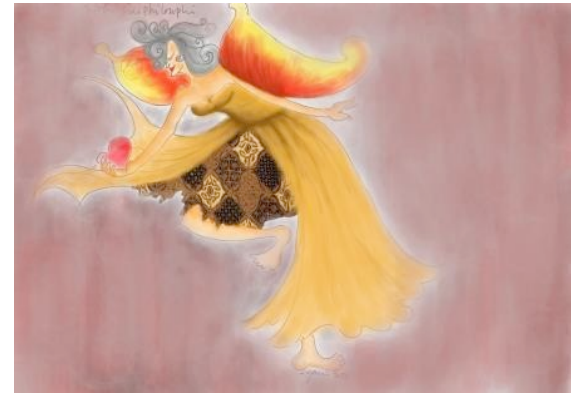

Figure 7. Tarian Terbang, $150 \times 150 \mathrm{~cm}$, acrylic on canvas, 2017

The visualization of this painting shows the aesthetic values of sidodrajat pattern as its creation source. Although it is presented in contemporary style, the meanings of the symbols are still relevant to the philosophical values of si-dodrajat batik. Hence, this painting has successfully repre-sented the local wisdoms that are relevant to the present life.

\section{Conclusion}

Based on the process and the paintings discussed in the previous section, it is confirmed that the aesthetic and philosophical values of classical batik are potential source of ideas to create paintings. Various contemporary painting styles interpret classical batik into different ways. The uni-versality of the meanings contained in the three classical batiks discussed (sidoasih, sidomulyo, sidodrajat) makes the meanings of the paintings are still relevant to the current situation.

\section{ACKNOWLEDGEMENT(S)}

The authors wish to thank Universitas Sebelas Maret that has provided the research grants 2017 on this classical batik aesthetics research so that it can run well on target.

\section{REFERENCES}

[1] Haryanto, "Seni Rupa Kontemporer di Yogyakarta Sejak Tahun 1975 Hingga 2010: Identitas dan Perubahan", Doctoral thesis summary, Graduate school of UGM, Yogyakarta, 2015.
[2] S. Budi, "Enam Motif Batik Klasik dan Satu Lurik dalam Sistem Nilai Ritual Mitoni Masyarakat Surakarta", Doctoral thesis, PPS ISI, Yogyakarta, 2017.

[3] Irianto, Asmudjo Jono, 2005, Ruang Urban di Indonesia dan Seni rupa Kontemporer in CP Biennale 2005: Urban/Culture, Jakarta.

[4] Sugiharto, I Bambang, 2016, Seni dan Paradigma Abad

21. An article in ARTJOG discussion, Yogyakarta.

[5] Sustiawati, Ni Luh , 2009, Seni Sebagai Pemberi Identitas Dalam Upaya Meningkatkan Daya Saing Bangsa. An article in national workshop and seminar of nation"s character development, Universitas Widyatama Bandung.

[6] Nairne, Sandy, 1999, Exhibition of Contemporary Art in Contemporary Culture of Display (ed) Emma Baker, Yale University, New Heaven.

[7] Tabrani, Primadi, 1999, Menggali Konsep Kriya Tradisi Untuk Keunggulan Seni Rupa Indonesia Masa Depan. An article in Craft and Engineering Conver-ence, ITB, Bandung.

[8] Fraser Lu, Sylvia, 1985, Indonesian Batik: Processes, Patern, and Place, Oxford University, (oxford) Singapore.

[9] Torwesten, Hans, 1991, Vedanta: Heart of Hinduism, Grove Press, New York.

[10] Campbell, David, 1986, Mengembangkan Kreativitas, translated by AM. Mangunhardjana, Kanisius, Yogyakarta. 